\title{
Satellite rainfall estimates: new perspectives for meteorology and climate from the EURAINSAT project
}

\author{
Vincenzo Levizzani \\ Istituto di Scienze dell'Atmosfera e del Clima (ISAC), CNR, Bologna, Italy
}

\begin{abstract}
Satellite meteorology is facing a crucial period of its history since recent missions have revealed instrumental for quantitative rainfall measurements from space and newly conceived missions are at hand. International partnership is rapidly developing and research projects keep the community focused on rapidly developing research and operational issues. A perspective is given through the structure of EURAINSAT, a project of the 5th Framework Programme of the European Commission. Its key objective is the development of algorithms for rapidly-updated satellite rainfall estimations at the geostationary scale. The project is fostering international research on satellite rainfall estimations building a bridge between Europe and the U.S. for present and future missions.
\end{abstract}

Key words satellite meteorology - precipitation climate - nowcasting

\section{Introduction}

The latest generation sensors on board the Geostationary Operational Environmental Satellites (GOES) (Menzel and Purdom, 1994) and the upcoming METEOSAT Second Generation (MSG) Spinning Enhanced Visible and Infrared Imager (SEVIRI) (Schmetz et al., 1998) significantly enhance the ability of sensing cloud microstructure and precipitation forming processes (Levizzani et al., 2000, 2001) from a geostationary platform. A potential exists for improved instantaneous rainfall measurements from space by combining infrared (IR) and visible (VIS) with passive microwave (MW) observations with a more global perspective.

Mailing address: Dr. Vincenzo Levizzani, Istituto di Scienze dell'Atmosfera e del Clima (ISAC), CNR, Via Gobetti 101, 40129 Bologna, Italy; e-mail: v.levizzani@ isac. cnr.it
IR and VIS satellite rainfall estimates have long since been available and suffered from the difficulty in associating cloud top features to precipitation at ground level. IR methods were used for climate purposes or combined with radar measurements for nowcasting (recent examples are Vicente et al., 1998; Porcù et al., 1999; Amorati et al., 2000) and multispectral approaches start to become operational (e.g., Ba and Gruber, 2001).

Physically-based passive MW methods were developed mainly using data from the Special Sensor Microwave/Imager (SSM/I) and are based on several different physical principles (see for example Wilheit et al., 1994; Smith et al., 1998). Limitations of MW algorithms include the relatively large footprint and the low earth orbits not suitable for most of the operational strategies.

The combined use of MW and IR data for rainfall estimations was already recognized some time ago (Vicente and Anderson, 1993). Adler et al. (1993) used SSM/I data for monthly average rainfall estimations over wide areas and global products such as those of the Global Precipitation Climatology Project (GPCP) were 
conceived (for recent advances see Huffman et al., 2001). However, the need for hourly and instantaneous combined estimations was clearly recognized (e.g., Vicente, 1994; Vicente and Anderson, 1994; Levizzani et al., 1996). Several methods exist (Turk et al., 1999; Sorooshian et al., 2000; Todd et al., 2001) that make use of IR and MW at various degrees of complexity and targeting different rainfall regimes. Some of these are running operationally, granting that their validation requires additional work in the years to come. In particular, global rapidupdate estimates with near real-time adjustment of the thermal IR co-localized with MW-based rainrates are operationally very promising (Turk et al., 1999).

The algorithms for the Tropical Rainfall Measuring Mission (TRMM) Precipitation Radar (PR) require a special mention given the novelty and potential of the active instruments for future missions: an example is the TRMM algorithm 2A-25 (Iguchi et al., 2000). Combined MW and rain radar algorithms are relatively new and were developed for the TRMM Microwave Imager (TMI) and the PR (e.g., TRMM algorithm 2B-31, Haddad et al., 1997).

Finally, rainfall and humidity assimilation, and microphysical parameterizations for Numerical Weather Prediction (NWP) models, above all Limited Area Models (LAMs), and General Circulation Models (GCMs) open up the road to very effective operational meteorological applications that incorporate the verification of model output (Turk et al., 1997).

\section{EURAINSAT: the project}

EURAINSAT is a project partially funded by the European Commission with the aim of developing new satellite rainfall estimation methods at the geostationary scale for an operational use in short and very short range weather monitoring and forecasting. It will exploit the new channels in the VIS, NIR and IR of the MSG SEVIRI (see fig. 1) that will be launched in mid 2002. The project started in January 2001 and will last until December 2003.

The SEVIRI channels in the VIS and IR portion of the spectrum will gain better insights

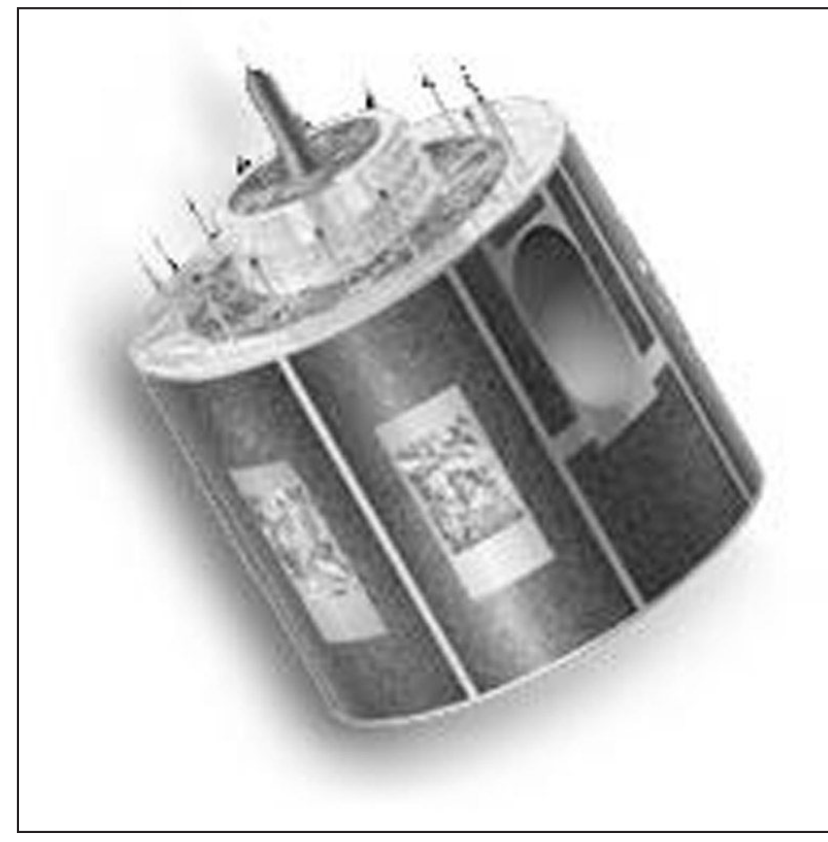

Fig. 1. Artist's impression of the METEOSAT Second Generation (MSG) spacecraft (courtesy of EUMETSAT).

into the microphysical and dynamic structure of precipitating clouds allowing for a more precise identification of precipitation levels. The method(s) will work as follows: 1) microphysical characterization of precipitating clouds with VIS/IR sensors; 2) creation of microphysical and radiative databases on cloud systems using cloud model outputs and aircraft penetrations; 3) tuning of MW algorithms on the different cloud systems (convective, stratiform, ...);4) combination of data from the different algorithms and application to a rapid update cycle that makes use of the different sensors at the geostationary scale.

The consortium has two objectives in mind: 1) contribute to improving the knowledge of clouds and precipitation formation processes using meteorological satellite sensors, and 2) make available new precipitation products for weather analysis and forecasting. SEVIRI will in fact provide better multispectral measurements for the identification of the physical processes of cloud formation and evolution. The $15 \mathrm{~min}$ image repetition time is also more compatible with the time responses of cloud systems.

The following key geographic areas and major meteorological events are considered: 
- Flood-producing episodes (e.g., Northwestern and Southern Italy).

- Several cases involving the presence/ absence of ice, polluted air masses and maritime conditions.

- Influence of orography, e.g., the Alps during the Mesoscale Alpine Programme (MAP) Special Observing Period (SOP) (Bougeault et al., 2001).

- Sustained light rain and «insignificant» rain cases (very difficult to detect from satellite) in U.K. and Northern Europe.

- Tropical and sub-tropical cases over Africa, where the Niger catchment was selected given the relatively regular ground raingage network.

- A climatological window over Europe (30-60 N, $15 \mathrm{~W}-20 \mathrm{E})$.

The project has gathered together a substantial part of the satellite rainfall community. The team actively participates into the development of scenarios and concept for the future Global Precipitation Measurement (GPM) Mission and the International Precipitation Working Group of the Coordination Group for Meteorological Satellites (CGMS). More information on EURAINSAT and its findings can be gained at the web site http://www.isac.cnr.it/ eurainsat.

\section{Microphysical characterization of cloud processes}

A method was developed by Rosenfeld and Lensky (1998) to infer precipitation-forming processes in clouds based on multispectral satellite data. The method was originally based on the Advanced Very High Resolution Radiometer (AVHRR) imagery on polar orbiting satellites (Lensky and Rosenfeld, 1997). The forthcoming MSG SEVIRI is expected to enhance the capabilities of extracting cloud physical properties (Watts et al., 1998) more relevant for cloud genesis and evolution and not anymore limited by the insufficient number of passages. The effective radius $\left(r_{e}\right)$ of the particles and cloud optical thickness are extracted and used for radiative transfer calculations that define the cloud type and improve its characterization.

Precipitation forming processes are inferred also using data from the AVHRR, the TRMM
VIS and IR Sensor (VIRS) and the MODerateresolution Imaging Spectroradiometer (MODIS) on board NASA's Terra spacecraft. In particular, microphysical and radiative parameters from satellite sensors are instrumental for defining the characteristics of precipitating clouds. An example of global cloud effective radius values derived from MODIS and ready to be used for EURAINSAT is given in fig. 2.

«Microphysically-maritime» clouds grow in relatively clean air with small Cloud Condensation Nuclei $(\mathrm{CCN})$ and low droplet concentrations, which produce very efficient coalescence and warm rain processes. «Continental» clouds normally grow, on the contrary, in polluted air masses having large $\mathrm{CCN}$ and high droplet concentrations, i.e. the coalescence is relatively inefficient. The better knowledge of cloud microphysical structure and precipitation forming processes will facilitate the development of a new generation of improved passive MW rainfall algorithms.

One more promising line of action is the potential use of lightning detection for discriminating between convective and stratiform regimes while estimating precipitation. Data from ground-based lightning detection networks and satellite sensors like the TRMM Lightning Imaging Sensor (LIS) are applied to IR rainfall estimations (Grecu et al., 2000) and show considerable potential for rapid update applications.

Above all, lightning detection represents a fast-response fundamental parameter for discriminating active convection and quantitative relationships have been found between lightning discharges and other measurables of rainfall (Petersen and Rutledge, 1998). Dietrich et al. (2001) have recently shown that the use of concurrent data from TRMM PR and LIS give unique information about the link between electrification and convection for the discrimination of convective and stratiform regimes. The authors hint at applications for rainfall retrieval using multispectral and MW techniques. The work is based upon the findings of Solomon and Baker (1998) who examined thunderstorm development and lightning flash rates in tropical maritime, subtropical continental, and midlatitude continental storms. The 


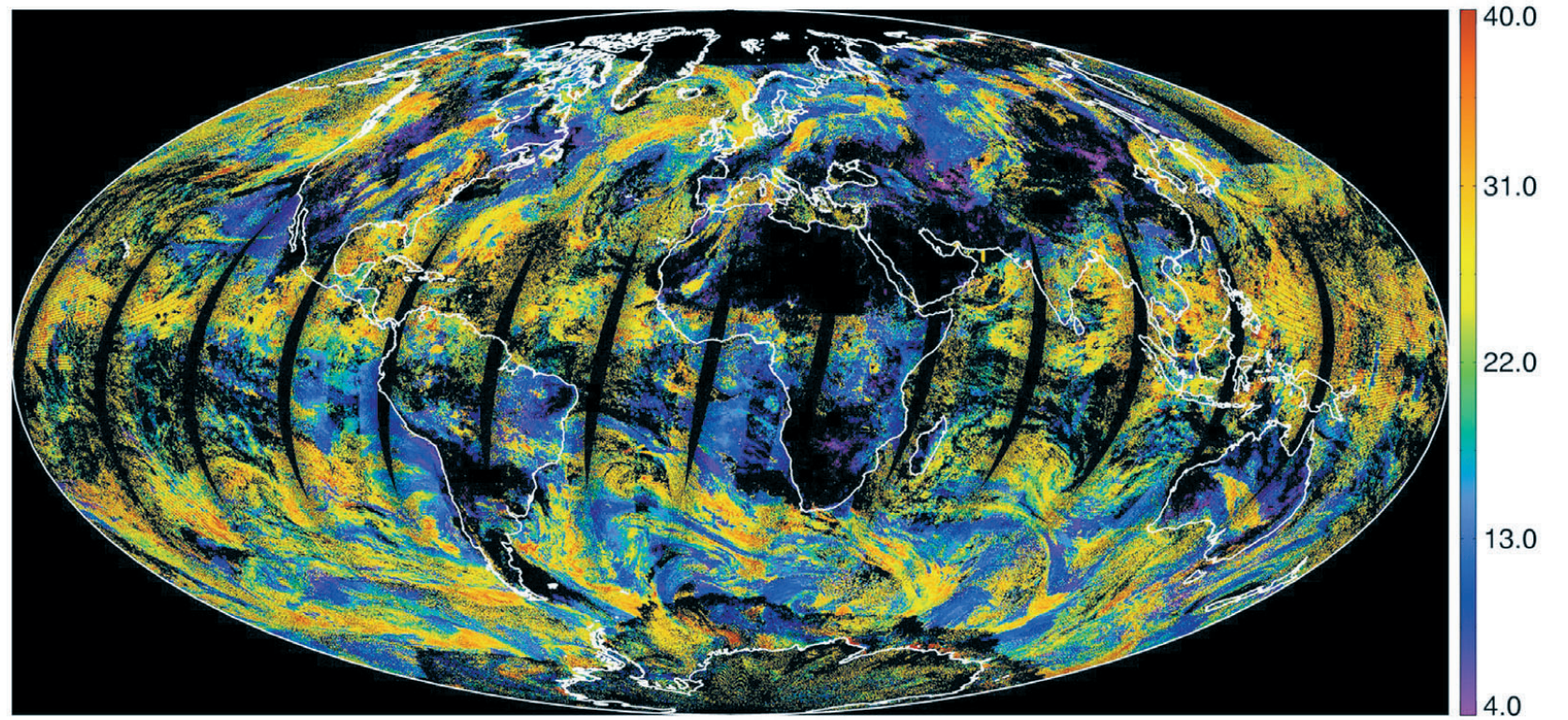

Fig. 2. Combined cloud effective radius retrievals derived for water-phase, ice-phase, and undetermined-phase clouds (10 October, 2001). Image courtesy of MODIS Atmosphere Discipline Group (http://modis-atmos. gsfc.nasa.gov/).

dependence of lightning occurrence and flash rate on cloud condensation nucleus concentration, primary and secondary glaciation mechanism, liquid water flux, and updraft velocity is of fundamental importance.

\section{Rainfall estimation methods}

\subsection{IR methods}

IR-based rainfall estimation methods were the first to be applied to a wide variety of scales and phenomena. With the advent of MW sensors they were more and more confined to large scale and climate applications. At the instantaneous time scale, methods based on thermal IR data are being integrated by ancillary information, such as data from radar, other VIS, IR and NIR channels, lightning detection, model output and other meteorological parameters.

For example, Porcù et al. (1999) have conceived a simple method to ensure a more physical relationship between cloud structure and precipitation rates as derived from the IR thresholding Negri-Adler-Wetzel (NAW) technique (Negri et al., 1984) by using SSM/I observations. A low-rainrate event with orographic forcing and small scale precipitation in Piedmont (NW Italy) on 13-16 October 2000 was considered over a $25000 \mathrm{~km}^{2}$ area to document the impact of the calibration on low precipitation NAW areas; nine SSM/I overpasses were available over the target basin (Porcù et al, 2000). The impact on the basin-averaged rainfall is rather low, resulting in a slight decrease of satellite overestimation for higher rainrates. The effect of calibration is more evident over the directly calibrated locations, given the very low occurrence of high precipitation areas during the event. The calibration helps for the higher rainrate peaks, while there is a marked underestimation of lower rainrates that is not affected by the calibration. The scattering of the points also increases showing an overall overestimation even for the highest rainrates. The calibration of low precipitation areas does not affect the performance of the technique as 
to the peak rainrates and does not reduce the underestimation for light rain, since it has no effects on the rain/no rain threshold.

\subsection{MW passive and active methods}

Many methods have been proposed for measuring rainfall from MW satellite sensors. Simple methods using polarization-corrected brightness temperatures (PCT) (e.g., Kidd, 1998) have been proposed together with more physical approaches that rely upon microphysical characterization by:

- stratifying clouds into different microphysical types and examining how much of the variability in the bias of MW rainfall estimation is explained by the microphysical characterization;
- developing a library of passive MW signatures from different cloud types, and

- using a microphysical cloud classification for improving cloud radiative transfer modeling based on statistical multivariate generators of cloud genera.

Figure 3 shows an example of MW rainfall retrieval over the Mediterranean and Western Europe using the algorithm by Turk et al. (1999) and data from SSM/I, TMI and the Advanced Microwave Sounding Unit-B (AMSU-B). More details can be found in Berg et al. (1998).

The scheme of Mugnai et al. (1993) and Smith et al. (1992) is a good example of such methods, especially in the very complex environment of severe storm microphysics. Cloud modeling and MW radiative transfer has been recently applied to stratiform rainfall by Bauer et al. (2000). Panegrossi et al. (1998) have

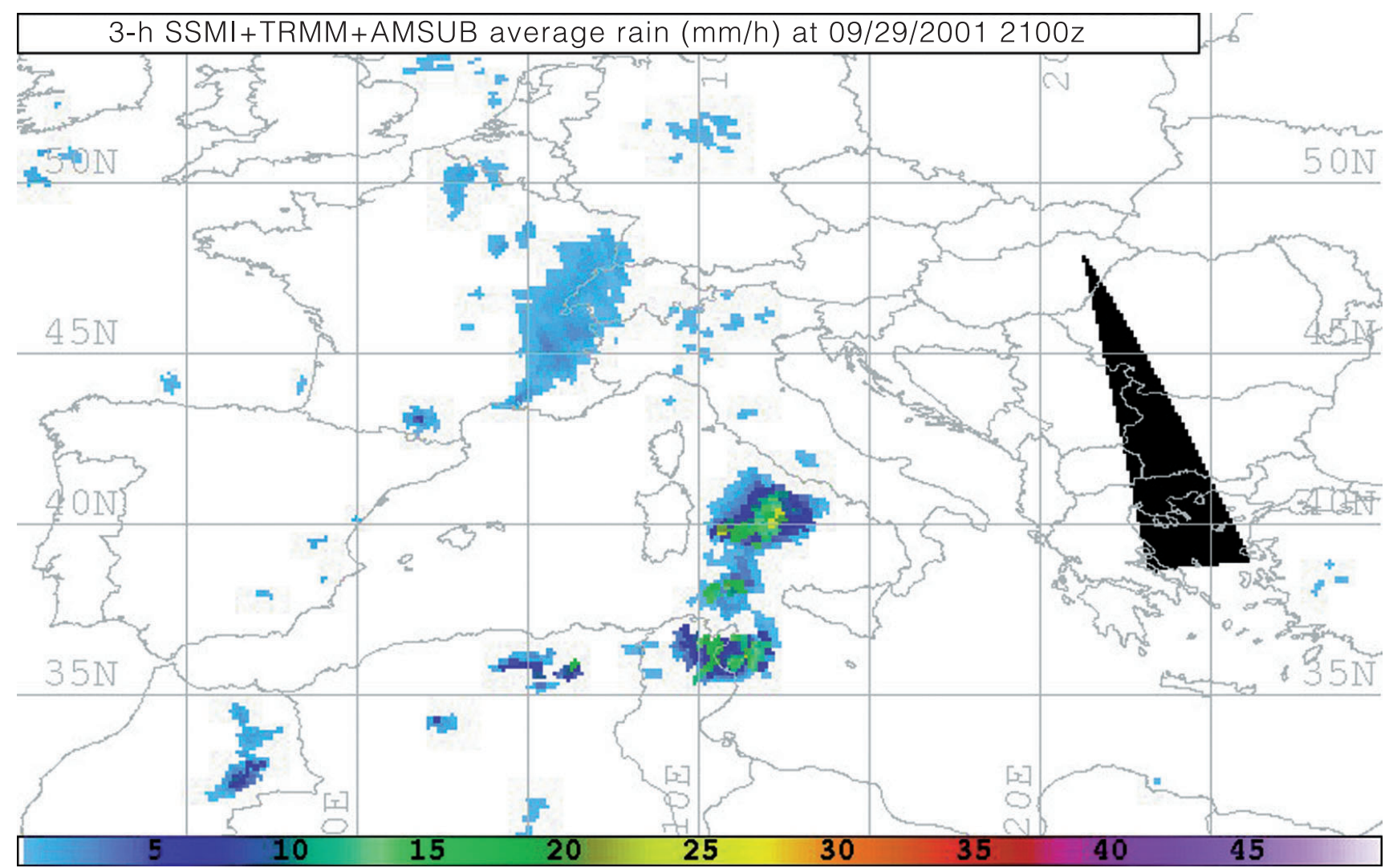

Fig. 3. 3-h average rainrate using a combined SSM/I, TMI and AMSU-B algorithm (29 September, 2001). Note the storm system stretching from the Tyrrhenian Sea to Tunisia. The black triangle indicates lack of data coverage after the mosaic of the satellite overpasses. Image courtesy of J.F. Turk (http://www.nrlmry.navy.mil/ sat_products.html). 
shown the importance of testing the physical initialization and the consistency between model and measurement manifolds. Research trends concentrate on improving the interpretation of active and passive MW measurements through better modeling of cloud processes such as the melting layer (Bauer, 2001a; Olson et al., 2001a,b). The TRMM satellite has set the path to new algorithms that still mostly work over oceans (e.g., Bauer, 2001b), but new developments are at hand over land (Grecu and Anagnostou, 2001). Polarization and texture information from passive radiometers together with $\mathrm{PR}$ data complete the scenario of new methods (Olson et al., 2001c). Ferreira et al. (2001) have recently contributed to the improvement of the TRMM 2A-25 algorithm (Iguchi et al., 2000) proposing the use of $\Gamma$ drop size distributions and $R-k$ relations instead of $R-Z$ (where $R$ is rainrate, $k$ the attenuation coefficient, and $Z$ the reflectivity).

The importance of separating convective and stratiform precipitation and stratiform and transition regions in the a priori cloud model database of MW algorithms is demonstrated by Kummerow et al. (2001). The authors document the latest improvements to the Goddard PROFiling algorithm (GPROF) as applied to the TRMM data. The new algorithm also uses the emission and scattering indexes instead of individual brightness temperatures. These improvements, together with the elimination of some classification ambiguities over land, are general and apply to other algorithms as well.

Fundamental ancillary data are finally provided by active and passive MW radiometry for Cloud Liquid Water (LWC) profiling: measurements from ground based MW radiometers combine with $Z$ profiles from cloud radars and cloud model statistics to lower the errors in LWC measurements by as much as 10-20\% (Löhnert et al., 2001).

\subsection{Combined multispectral and MW methods}

Cloud microphysical information, when combined with MW measurements, can lead to improvements in satellite-based rainfall measurements, especially from clouds in the extra tropics and over land (e.g., Bauer et al.,
1998). EURAINSAT concentrates on exploiting SEVIRI data in the VIS, NIR and Water Vapor (WV) for cloud characterization and screening within a rapid cycle of rainfall estimation based on SSM/I, TMI and geostationary IR data. Data from MODIS simulate MSG SEVIRI data during the pre-launch phase. Moreover, the project shares in the cloud-related work from the MODIS team (King et al., 1997).

There are two main research lines:

- Develop new MSG-MW rainfall algorithms incorporating the observed cloud microstructure and precipitation forming processes. State of the art cloud and mesoscale models (Khain et al., 2000; Tripoli et al., 2001) and radiative transfer models will be instrumental to detailed cloud and rainfall type discrimination. The need to use such frontier cloud model was recently shown by Khain et al. (2001) who demonstrated the weakness of existing cloud parameterizations while trying to give reason of highly supercooled water in convective clouds $\left(1.8 \mathrm{~g} \mathrm{~m}^{-3}\right.$ at $\left.-37.5^{\circ} \mathrm{C}\right)$ as found by Rosenfeld and Woodley (2000).

- Introduce such methods into rapid update rainfall cycles for near real time rainfall estimations over oceans and land with the widest possible area coverage. Mid-latitude Europe, the Mediterranean basin, North Africa, the Middle East and equatorial and tropical African regions are the main targets for operational and climatological applications. Applications to the Mediterranean have been reported by Meneguzzo et al. (1998).

\section{Applications}

Applications embrace, among others, water availability, global change studies, nowcasting, hydrogeological disaster management, agriculture, famine reduction, and monitoring of remote areas.

\subsection{Rainfall assimilation for NWP}

Data assimilation procedures that improve cloud and humidity characterization in current analysis schemes for LAMs are at hand. Most important are the sensitivity to orography 
and modeling of moist processes. The model BOLAM (Buzzi et al., 1998) is used in the project to conduct rainfall assimilation experiments that quantify the impact of satellite data onto the forecasting chain. The nudging technique of Falcovich et al. (2000) is adopted. Motivations for using nudging techniques are that nudging to over-saturation is more gradual, and the reference profile is useful in tropical areas. The model is now applied to autumn rainfall episodes over the Mediterranean.

The model RAMS (Pielke et al., 1992) is also used and runs operationally in Tuscany with two grids, that are two-way nested and with the highest horizontal spatial resolution of $4 \mathrm{~km}$ around Tuscany and the Arno river basin. The complex cloud microphysics scheme is fully activated (Walko et al., 1995), while the Kuotype convection parameterization (Molinari, 1985 ) is activated only over the $20 \mathrm{~km}$ outer grid and explicit (resolved) convection is allowed over the inner grid. A higher spatial horizontal resolution of $2 \mathrm{~km}$ will be reached to ensure fully consistent explicit representation of the convection. Quantitative Precipitation Forecasts (QPFs) are produced hourly over the inner grid. Diabatic initialization and rainfall assimilation will be conducted in the operational chain before the end of the project.

\subsection{Rainfall and climate change}

The importance of multispectral cloud characterization methods has recently been demonstrated by observing and documenting the inhibiting effects of forest fire (Rosenfeld, 1999), urban pollution (Rosenfeld, 2000) and desert dust aerosols (Rosenfeld et al., 2001) on precipitation formation processes. It is very likely that rainfall processes have been substantially underestimated against, for example, greenhouse gases in evaluating possible causes of climate changes. A more quantitative assessment is, however, necessary.

In particular, Ramanathan et al. (2001) argue that manmade aerosols produce brighter clouds with reduced precipitation efficiency and rainfall suppression. This can lead to a weaker hydrological cycle, which connects directly to water availability and quality, a major environmental issue of the 21 st century.

Satellite rainfall data are used also to assess the impact of particular weather systems on the geographical, seasonal and interannual distribution of total rainfall. Rodgers et al. (2000) have concentrated on the impact of tropical cyclones on the North Pacific climatological rainfall. The same authors have repeated the study for the North Atlantic (Rodgers et al., 2001). Such studies are crucial for the quantification of climatic effects and their relationships with indicators such as the El Niño Southern Oscillation (ENSO) and the North Atlantic Oscillation (NAO). Databases of global products such as those of the GPCP (Huffman et al., 2001) will be very useful for supporting the definition of new local indexes that better describe regional variations, observed over smaller basins like the Mediterranean.

\subsection{Attenuation of satellite communications due to rainfall}

Over the last few years, there has been an increasing demand of large-bandwidth information services coupled with high availability and low-fade margin communication systems (Watson and $\mathrm{Hu}, 1994)$. This scenario has prompted exploring channel frequencies at Ka band and above, and developing sophisticated countermeasure techniques to mitigate outage periods (Jones and Watson, 1993). The implementation of most advanced adaptive countermeasure techniques is related to the possibility of monitoring in quasi real-time the beacon attenuation in a given region and period. Spatial and frequency diversity methods, power link control, data rate and error correction on the downlink/uplink can be effectively adopted only if the propagation conditions are known in real time.

Exploitation of remote sensors and their products represents a natural way to optimize the performances of a satellite communication system with low power margins, specifically while applying fade mitigation techniques. MW signatures of precipitation, as given by a spaceborne multi-frequency radiometer, have been shown to be the base for estimating the path 
attenuation in K-band satellite communications (Marzano et al., 2000). A general approach should attempt to estimate rainfall intensity and attenuation by polar-orbiting MW radiometers and temporally track the rain system by means of geostationary IR radiometers. A statistical approach can be used to derive a prediction model of path attenuation from MW brightness temperature and surface rainrate (Crone et al., 1996).

\section{Acknowledgements}

The work was partially funded by the Project EURAINSAT, a shared-cost project (contract EVG1-2000-00030) co-funded by the Research DG of the European Commission within the RTD activities of a generic nature of the Environment and Sustainable Development sub-programme (5th Framework Programme). Partial support is acknowledged from the Italian Space Agency (ASI) within the project Studio del Ciclo Idrologico da Piattaforme Satellitari: Nubi e Precipitazioni, and from the Italian Group for Prevention from Hydrogeological Disasters (GNDCI).

\section{REFERENCES}

ADLER, R.F., A.J. NEGRI, P.R. KEEHN and I.M. HAKKARINEN (1993): Estimation of monthly rainfall over Japan and surrounding waters from a combination of low-orbit microwave and geosynchronous IR data, J. Appl. Meteorol., 32, 335-356.

Amorati, R., P.P. Alberoni, V. LEVIZZANI and S. NANNI (2000): IR-based satellite and radar rainfall estimates of convective storms over Northern Italy, Meteorol. Appl., 7, 1-18.

BA, M.B. and A. GRUBER (2001): GOES Multispectral Rainfall Algorithm (GMSRA), J. Appl. Meteorol., 40, $1500-1514$.

BAUER, P. (2001a): Microwave radiative transfer simulation in clouds: including a melting layer in cloud model bulky hydrometeor distributions, Atmos. Res., 157, 9-30.

BAUER, P. (2001b): Over-ocean rainfall retrieval from multisensor data of the Tropical Rainfall Measuring Mission. Part I: design and evaluation of inversion databases, J. Atmos. Oceanic Technol., 18, 1315-1330.

BAuer, P., L. Schanz, R. BENNARTZ and P. SCHLÜSSEL (1998): Outlook for combined TMI-VIRS algorithms for TRMM: lessons learned from the PIP and AIP projects, J. Atmos. Sci., 55, 1714-1729.
Bauer, P., A. Khain, A. Pokrovsky, R. Meneghini, C. Kummerow, F.S. Marzano and J.P.V. Poiares BAPTISTA (2000): Combined cloud-microwave radiative transfer modeling of stratiform rainfall, J. Atmos. Sci., 57, 1082-1104.

Berg, W., W. Olson, R. Ferraro, S.J. Goodman and F.J. LAFONTAINE (1998): An assessment of the firstand second-generation Navy operational precipitation retrieval algorithms, J. Atmos. Sci., 55, 1558-1575.

Bougeault, P., P. Binder, A. BuZzi, R. Dirks, R. Houze, J. Kuettner, R.B. Smith, R. Steinacker and H. VOLKERT (2001): The MAP Special Observing Period, Bull. Am. Meteorol. Soc., 82, 433-462.

Buzzi, A., N. TARTAglione and P. Malguzzi (1998): Numerical simulations of the 1994 Piedmont flood: role of orography and moist processes, Mon. Weather Rev., 126, 2369-2383.

Crone, L.J., L.M. MCMillin and D.S. Crosby (1996): Constrained regression in satellite meteorology, J. Appl. Meteorol., 35, 2023-2039.

Dietrich, S., R. Solomon, C. Adamo and A. Mugnai (2001): Rainfall monitoring at geostationary scale: potential of lightning data in a rapid update approach, in Proceedings 2001 EUMETSAT Meteorological Data Users' Conference, Antalya, 393-398.

FALCOVICH, A., E. KALNAY, S. LORD and M.B. MATUR (2000): A new method of observed rainfall assimilation in forecast models, J. Appl. Meteorol., 39, 1282-1298.

Ferreira, F., P. AmAYenC, S. OURY and J. TESTUd (2001): Study and test of improved rain estimates from the TRMM precipitation radar, J. Appl. Meteorol., 40, 1878-1899.

Grecu, M. and E.N. AnAgnostou (2001): Overland precipitation estimation from TRMM passive microwave observations, J. Appl. Meteorol., 40, 1367-1380.

Grecu, M., E.N. Anagnostou and R.F. AdLer (2000): Assessment of the use of lightning information in satellite infrared rainfall estimation, J. Hydrometeorol., 1, 211-221.

Haddad, Z., E.A. SMith, C. Kummerow, T. IGUChi, M. FARRAR, S. DARDEN, M. AlVES and W. Olson (1997): The TRMM 'Day-1' radar/radiometer combined rain-profile algorithm, J. Meteorol. Soc. Japan, 75, 799-808.

Huffman, G.J., R.F. Adler, M.M. Morrissey, D.T. Bolvin, S. Curtis, R. JOYCE, B. MCGAVOCK and J. SUSSKIND (2001): Global precipitation at one-degree daily resolution from multisatellite observations, $J$. Hydrometeorol., 2, 36-50.

Iguchi, T., T. Kozu, R. Meneghini, J. AwakA and K. ОкАмОто (2000): Rain-profiling algorithm for the TRMM precipitation radar, J. Appl. Meteorol., 39, 2038-2052.

JONES, S.M.R. and P.A. WATSON (1993): Attenuation and countermeasures in millimeter-wave point-to-multipoint networks, Radio Sci., 28, 1057-1069.

Khain, A., M. Ovtchinnikov, M. Pinsky, A. Pokrovsky and H. KRUGLIAK (2000): Notes on the state-of-the-art numerical modeling of cloud microphysics, Atmos. Res., $\mathbf{5 5}, 159-224$.

Khain, A.P., D. Rosenfeld and A. Pokrovsky (2001): 
Simulating convective clouds with sustained supercooled liquid water down to -37.5 degrees $\mathrm{C}$ using a spectral microphysics model, Geophys. Res. Lett., 28, 3887-3890.

KIDD, C. (1998): On rainfall retrieval using polarizationcorrected temperatures, Int. J. Remote Sensing, 19, 981-996.

King, M.D., S.-C. Tsay, S.E. Platnick, M. Wang and K.-N. LIOU (1997): Cloud retrieval algorithms for MODIS: optical thickness, effective particle radius, and thermodynamic phase, MODIS Algorithm Theoretical Basis Doc., ATBD-MOD-05 and MOD-06.

Kummerow, C., Y. Hong, W.S. Olson, S. YANG, R.F. Adler, J. McCollum, R. Ferraro, G. Petty, D.-B. SHIN and T.T. WILHEIT (2001): The evolution of the Goddard Profiling Algorithm (GPROF) for rainfall estimation from passive microwave sensors, J. Appl. Meteorol., 40, 1801-1820.

LENSKY, I.M. and D. RosENFELD (1997): Estimation of precipitation area and rain intensity based on the microphysical properties retrieved from NOAAAVHRR data, J. Appl. Meteorol., 36, 234-242.

Levizzani, V., F. Porcù, F.S. Marzano, A. Mugnai, E.A. SMITH and F. PRODI (1996): Investigating a SSM/I microwave algorithm to calibrate METEOSAT infrared instantaneous rainrate estimates, Meteorol. Appl., 3, $5-17$.

Levizzani, V., P.P. Alberoni, P. Bauer, L. Bottai, A. Buzzi, E. Cattani, M. Cervino, P. Ciotti, M.J. Costa, S. Dietrich, B. Gozzini, A. Khain, C. KidD, F.S. Marzano, F. Meneguzzo, S. Migliorini, A. Mugnai, F. Porcù, F. PRODI, R. RizZI, D. RosenFELD, L. SCHANZ, E.A. SMITH, F. TAMPIERI, F. TORRICELLA, F.J. TURK, G.A. VICENTE and G. ZIPOLI (2000): Use of the MSG SEVIRI channels in a combined SSM/I, TRMM and geostationary IR method for rapid updates of rainfall, in Proceedings 1st MSG-RAO Workshop, ESA SP-452, 63-66.

Levizzani, V., J. Schmetz, H.J. Lutz, J. Kerkmann, P.P. Alberoni and M. Cervino (2001): Precipitation estimations from geostationary orbit and prospects for METEOSAT second generation, Meteorol. Appl., 8, 23-41.

LÖHnert, U., S. Crewell, C. Simmer and A. Macke (2001): Profiling cloud liquid water by combining active and passive microwave measurements with cloud model statistics, J. Atmos. Oceanic Technol., 18, 1354-1366.

Marzano, F.S., J.F. Turk, P. CiotTi, S. Di Michele and N. PiERDICCA (2000): Combined use of spaceborne polar-orbiting microwave and geo-stationary infrared radiometers for estimating rainfall attenuation along earth-satellite links, in Proceedings 1st International Workshop on Radiowave Propagation Modelling for SatCom Services at Ku-band and Above, ESA WPP146, 189-196.

Meneguzzo, F., S. Migliorini, G.A. Vicente, L. Bottai, B. GozZINI and G. ZIPOLI (1998): Satellite rainfall estimates in real time in the Mediterranean countries. Verifications in Tuscany, in Proceedings ICAM-98, 25th International Conference on Alpine Meteorology, Turin, 14-19 July, 2-7.
MenZeL, W.P. and J.F.W. PuRdom (1994): Introducing GOES-I: the first of new generation of Geostationary Operational Environmental Satellites, Bull. Am. Meteorol. Soc., 75, 757-781.

MOLINARI, J. (1985): A general form of Kuo's cumulus parameterization, Mon. Weather Rev., 113, 1411-1416.

Mugnai, A., E.A. Smith and G.J. Tripoli (1993): Foundations for statistical-physical precipitation retrieval from passive microwave satellite measurements. Part II: emission-source and generalized weighting-function properties of a time-dependent cloud-radiation model, J. Appl. Meteorol., 32, 17-39.

NegRI, A.J., R.F. AdLER and P.J. Wetzel (1984): Rain estimation from satellite: an examination of the Griffith-Woodley technique, J. Climate Appl. Meteorol., 23, 102-116.

OLSON, W.S., P. BAUER, N.E. ViltARD, D.E. JOHNSON, W.-K. TAO, R. MENEGHINI and L. LIAO (2001a): A meltinglayer model for passive/active microwave remote sensing applications. Part I: model formulation and comparison with observations, J. Appl. Meteorol., 40, 1145-1163.

Olson, W.S., P. BAuER, C.D. KumMEROW, Y. HONG and W.-K. TAO (2001b): A melting-layer model for passive/ active microwave remote sensing applications. Part II: simulation of TRMM observations, J. Appl. Meteorol., 40, 1164-1179.

Olson, W.S., Y. HONG, C.D. KumMEROW and J.F. TuRK (2001c): A texture-polarization method for estimating convective-stratiform precipitation area coverage from passive microwave radiometer data, J. Appl. Meteorol., 40, 1577-1591.

PAnegrossi, G., S. Dietrich, F.S. Marzano, A. Mugnai, E.A. Smith, X. Xiang, G.J. Tripoli, P.K. Wang and J.P.V. POIARES BAPTISTA (1998): Use of cloud model microphysics for passive microwave-based precipitation retrieval: significance of consistency between model and measurement manifolds, J. Atmos. Sci., 55, 16441672.

PETERSEN, W.A. and S.A. RuTLEDGE(1998): On the relationship between cloud-to-ground lightning and convective rainfall, J. Geophys. Res., 103, 14,025-14,040.

PielKe, R.A., W.R. CotTon, R.L. WALKo, C.J. TREMBACK, W.A. Lyons, L.D. Grasso, M.E. Nicholls, M.D. Moran, D.A. WeSLEY, T.J. LEE and J.H. COPELAND (1992): A comprehensive meteorological modeling system - RAMS, Meteorol. Atmos. Phys., 49, 69-91.

PorcÙ, F., M. BORGA and F. Prodi (1999): Rainfall estimation by combining radar and infrared satellite data for nowcasting purposes, Meteorol. Appl., 6, 289-300.

Porcù, F., F. Prodi, S. Dietrich, A. Mugnai and R. BECHINI (2000): Multisensor estimation of severe rainfall events, in Proceedings of the 2000 EUMETSAT, Meteorological Satellite Data Users' Conference, EUM P 29, EUMETSAT, 371-378.

Ramanathan, V., P.J. Crutzen, J.T. Kiehl and D. ROSENFELD (2001): Aerosols, climate and the global environment. A hazy future for the blue planet?, Science, 294, 2119-2124.

Rodgers, E.B., R.F. Adler and H.F. Pierce (2000): Contribution of tropical cyclones to the North Pacific climatological rainfall as observed from satellite, J. Appl. 
Meteorol., 39, 1658-1678.

Rodgers, E.B., R.F. AdLer and H.F. PierCe (2001): Contribution of tropical cyclones to the North Atlantic climatological rainfall as observed from satellite, J. Appl. Meteorol., 40, 1785-1800.

ROSENFELD, D. (1999): TRMM observed first direct evidence of smoke from forest fires inhibiting rainfall, Geophys. Res. Lett., 26, 3105-3108.

RosENFELD, D. (2000): Suppression of rain and snow by urban and industrial air pollution, Science, 287, 1793-1796.

ROSENFELD, D. and I.M. LENSKY (1998): Satellite-based insights into precipitation formation processes in continental and maritime convective clouds, Bull. Am. Meteorol. Soc., 79, 2457-2476.

RosenfELD, D. and W.L. WoODLEY (2000): Deep convective clouds with sustained supercooled liquid water down to-37.5 degrees C, Nature, 405, 440-442.

Rosenfeld, D., Y. RUDich and R. LAHAV (2001): Desert dust suppressing precipitation: a possible desertification feedback loop, Proc. Nat. Acad. Sci., 98, 5975-5980.

SCHMETZ, J., H. WOICK, S.A. TJEMKES and M. RATTENBORG (1998): From METEOSAT to METEOSAT Second Generation (MSG), in Preproceedings of the 9th Conference on Satellite Meteorology and Oceanography, AMS, 335-338.

SMith, E.A., A. Mugnai, H.J. CoOPER, G.J. TRIPOLI and X. XIANG (1992): Foundations for statistical-physical precipitation retrieval from passive microwave satellite measurements. Part I: brightness-temperature properties of a time-dependent cloud-radiation model, J. Appl. Meteorol., 31, 506-531.

Smith, E.A., J.E. LAmm, R.F. AdLer, J. Alishouse, K. Aonashi, E.C. Barrett, P. Bauer, W. Berg, A. Chang, R. Ferraro, J. Ferriday, S. GoOdman, N. Grody, C. KidD, D.R. KNIVETON, C. KuMMEROW, G. Liu, F.S. Marzano, A. Mugnai, W. Olson, G. Petty, A. ShibAtA, R. SPEnCER, F. Wentz, T. Wilheit and E. ZIPSER (1998): Results of the WetNet PIP-2 project, J. Atmos. Sci., 55, 1483-1536.

SOLOMON, R. and M.B. BAKER (1998): Lightning flash rate and type in convective storms, J. Geophys. Res., 103, $14,041-14,057$

Sorooshian, S., K.-L. Hsu, X. GaO, H.V. GuPTA, B. IMAM and D. BRAITHWAITE (2000): Evaluation of PERSIANN system satellite-based estimates of tropical rainfall, Bull. Am. Meteorol. Soc., 81, 2035-2046.

TodD, M.C., C. KidD, D. Kniveton and T.J. Bellerby (2001): A combined satellite infrared and passive microwave technique for estimation of small-scale rainfall, J. Atmos. Oceanic Technol., 18, 742-755.

Tripoli, G.J., G. PANEgrossi, A. Mugnai, S. DiEtrich and E.A. SMith (2001): A numerical study of the Friuli, 1998 and the Genoa, 1992 floods, Mediterranean Storms
2000, edited by A. Mugnai, F. Guzzetti and G. Roth (in press).

TURK, F.J., G.D. ROHALY and P. ARKIN (1997): Utilization of satellite-derived tropical rainfall for analysis and assimilation into a numerical weather prediction model, in Preproceedings of the 22nd Conference on Hurricanes and Tropical Meteorology, AMS, 310-311.

Turk, F.J., G.D. Rohaly, J. Hawkins, E.A. SMith, F.S. Marzano, A. Mugnai and V. Levizzani (1999): Meteorological applications of precipitation estimation from combined SSM/I, TRMM and infrared geostationary satellite data, in Microwave Radiometry and Remote Sensing of the Earth's Surface and Atmosphere, edited by P. PAMPALONI and S. PALOSCIA (VSP Int. Sci. Publ.), 353-363.

VICENTE, G.A. (1994): Hourly retrieval of precipitation rate from the combination of passive microwave and infrared satellite radiometric measurements, Ph.D. Thesis, Department of Atmospheric and Oceanic Sciences, University of Wisconsin - Madison, WI, U.S.A.

ViCENTE, G.A. and J.R. ANDERSON (1993) Retrieval of rainfall rates from the combination of passive microwave radiometric measurements and infrared measurements, in Preproceedings of the 20th Conference on Hurricane and Tropical Meteorology, AMS, 151-154.

VICENTE, G.A. and J.R. ANDERSON (1994): A new rain retrieval technique that combines geosynchronous IR and MW polar orbit data for hourly rainfall estimates. Case Study: Kwajalein and TOGA-COARE, in Preproceedings of the 7th Conference on Satellite Meteorology and Oceanography, AMS, 34-37.

VICENTE, G.A., R.A. SCOFIELD and W.P. MENZEL (1998): The operational GOES infrared rainfall estimation technique, Bull. Am. Meteorol. Soc., 79, 1883-1898.

WAlko, R.L., W.R. CotTon, M.P. Meyers and J.Y. HARRINGTON (1995): New RAMS cloud microphysics parameterization. Part I: the single-moment scheme, Atmos. Res., 38, 29-62.

WATSON, P.A. and Y.F. Hu (1994): Prediction of attenuation on satellite-earth links for systems operating with low fade margins, IEEE Proceedings-Microwaves Antennas and Propagation, 141, 467-472.

WATTS, P.D., C.T. MutLOW, A.J. BARAN and A.M. ZAVODY (1998): Study on cloud properties derived from METEOSAT Second Generation observations, Final Report, EUMETSAT ITT n. 97/181 (Darmstadt, Germany), pp. 344.

Wilheit, T.T., R.F. Adler, S. Avery, E. Barrett, P. BAuer, W. Berg, A. Chang, J. Ferriday, N. Grody, S. GOODMAN, C. KIDD, D. KNIVETON, C. KUMMEROW, A. Mugnai, W. Olson, G. PetTy, A. Shibata, E.A. Smith and R. SPENCER (1994): Algorithms for the retrieval of rainfall from passive microwave measurements, Remote Sensing Rev., 11, 163-194. 